\title{
THE SITE OF SAN CALOCERO DI ALBENGA (SV). AN INTER-DISCIPLINARY METHODOLOGICAL TRAINING GROUND
}

\author{
S. Roascio ${ }^{1,2} *$ \\ ${ }^{1}$ Ministero per i Beni e le Attività Culturali, Parco Archeologico dell'Appia Antica, Roma, Italy - stefano.roascio@ beniculturali.it. \\ ${ }^{2}$ Laboratoire d'Archéologie Médiévale et Moderne en Méditerranée, Université d'Aix-Marseille, Marseille, France - \\ stefano.roascio@beniculturali.it.
}

KEY WORDS: archaeology, archaeometry, radiometric dating of lime clumps, Albenga, San Calocero, minero-petrographic analysis

\begin{abstract}
:
This paper summarizes the results of the research on the site of San Calocero di Albenga where, in late antiquity, a martyrial sanctuary was built on the remains of a probable funerary enclosure of the late imperial era. This site is known since the first half of the twentieth century for the pioneering research of Nino Lamboglia both in the field of the first experiences of stratigraphic archaeology and for an embryonic reading of the walls. After further investigations by the Soprintendenza della Liguria, the archaeological complex has been the subject of new studies since 2014. At this moment, the Politecnico di Milano was involved in surveying activities, and extensive use of archaeometric investigations was made. In particular, the minero-petrographic analysis of the mortars and the $\mathrm{C} 14$ on the lime clumps allowed reaching new significant knowledge in the scanning of construction activities and their dating.
\end{abstract}

\section{INTRODUCTION}

\subsection{San Calocero in the past and today}

The site of S. Calocero - a multi-layered complex that in the late antiquity saw the construction of a true martyrdom basilica - is of vital importance for the interdisciplinary approaches, because of a fortunate and probably casual series of events. In this place, in the Nineteen-thirties, a very young Nino Lamboglia laid the foundations for both the stratigraphic archaeology and the scientific methods in excavating late ancient and medieval contexts (Lamboglia, 1947; Roascio, 2010). Between the Eighties and Nineties, the Soprintendenza Archeologica della Liguria undertook significant operations of protection, restoration and enhancement and entrusted the direction of the excavation to the Christian archaeologist Philippe Pergola, who shared the responsibility with Giuseppina Spadea of the Soprintendenza (Pergola et al., 1990; Pergola and Roascio, 2010; Spadea, 2010). Also, the École française de Rome took an active part in these interventions, inaugurating once again the primacy of the first structured and multi-year international collaboration for the Ligurian Superintendence (Gras, 2010). In 2010, an inter-disciplinary monograph was published (Spadea et al., 2010), with the ambition to "take stock" of a research lasting decades, analysing multiple points of view, both purely archaeological and documentary or artistic. In this volume, after the pioneering experiences of Lamboglia, there was also the first stratigraphic reading of the elevations and functional analysis of the spaces of the entire building (Roascio and Gavagnin, 2010).

On the occasion of the studies for a $\mathrm{PhD}$ with international cosupervision by myself (Roascio, c.d.s.) the site was investigated again between 2014 and 2015 (Pergola et al., 2018). In this phase, the Politecnico di Milano also participated in the survey activities: dr. Riccardo Valente performed both the archaeological and topographical survey of the excavation, as well as the survey of some wall surfaces using a laser scanner, as part of training carried out by the School of Specialization of the same university. Furthermore, a series of archaeometric analyses were carried out, according to the typical methods of the archaeology of architecture. This paper summarizes these investigations (for a more complete dissertation, see also Roascio, Decri and Scrivano c.d.s.).

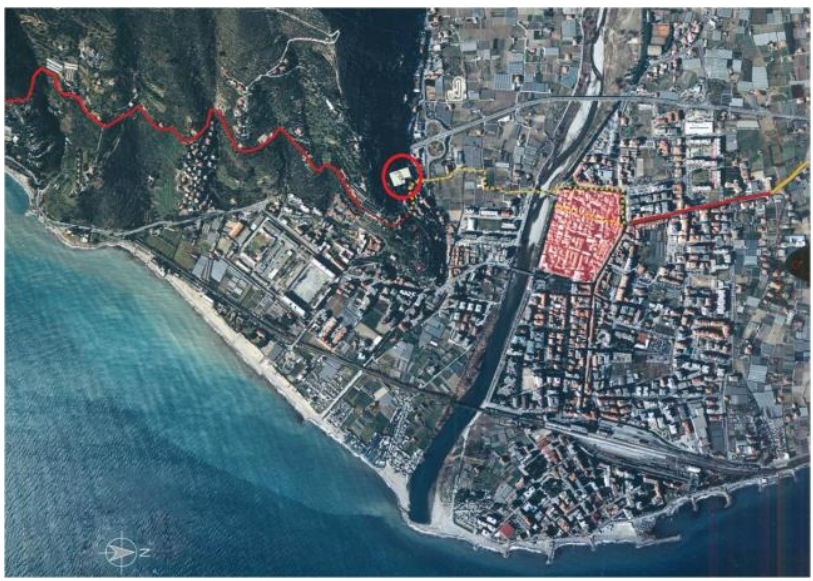

Figure 1. The location of San Calocero, in relation to the ancient city.

\section{MINERO-PETROGRAPHIC ANALYSIS}

\subsection{Survey methodology}

A first characterization analysis, to identify the fragments useful to define and descript the sample as a whole, was carried out on the samples by optical microscopy analysis through Digital 


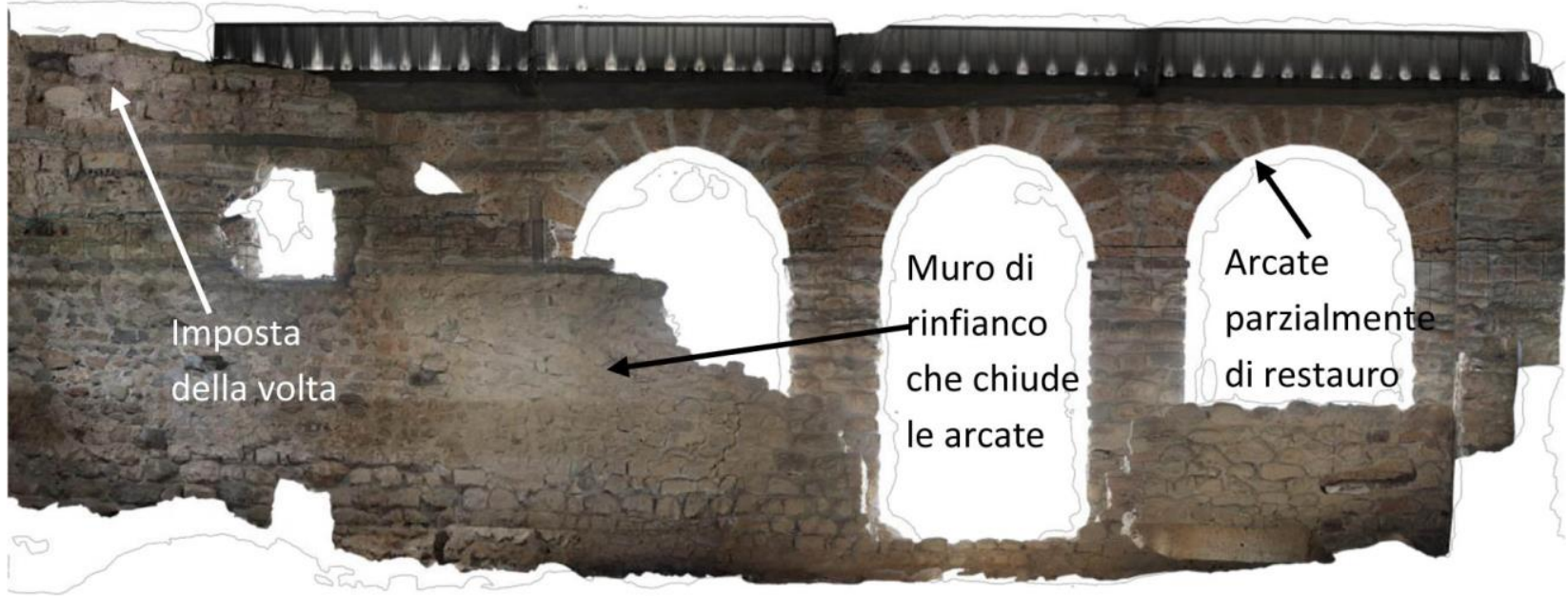

Figure 2. Laser-scanner survey of the late ancient arches (Politecnico di Milano).

Microscope from 35 to 250 magnifications (Image sensor: High resolution; still and video capture resolution: $1600 \times 1280$ pixels (2 Mpixels); focus range: manual focus from $10 \mathrm{~mm}$ to $500 \mathrm{~mm})$.

The samples were subsequently incorporated in transparent twocomponent resin in order to obtain shiny sections, which were observed by optical microscopy with an Optika B-350 microscope at 40, 100 and 400 enlargements.

The petrographic analysis of the 21 samples collected allowed their subdivision into seven groups characterized by different compositions.

All the samples have mineralogical associations compatible with the Centa river area. The compositional difference found in the binders can be ascribed both to the use of more or less pure limestone and to the addition of silicate minerals to increase the hydraulicity of the mortars.

\subsection{Analysis of the results}

The first group to be analysed is Group D: it includes the great late Roman L-shaped wall (C 7 and C 16), probably a funerary enclosure, on which the early Christian church is set; the same mortar also characterizes $C 113$, the semi-circular structure that leans on the eastern side of the same wall. Already while examining the masonry, it was evident that the building technique was particularly close, suggesting that the apparent support was the result of construction that was, in any case, close or belonging to a mere construction phase of the same building site, which would now seem to have been proved by the analysis of mortars. The deepest apse of the early Christian church also seems to belong to the same group; this datum would be in contradiction with the stratigraphic reading, which identifies the foundation of the church as subsequent to the Roman wall which, also with the $\mathrm{C} 14$, as we shall see, has been dated between the first and third centuries. It is possible to hypothesize that, being the two buildings comprised between the late imperial and the late ancient period, the sand supply basin for the mortar was always the same as well as the construction techniques.

Group A includes the arched wall on the $\mathrm{N}$ front (downstream) of the L-shaped wall (C 111) and some slender funerary structures $(\mathrm{C} 1 / 1, \mathrm{C} 3 / 1)$ found in the front excavation sector of the facade.

The data seems harmonious because of the relative chronological sequence deduced from the stratigraphy of the walls places the wall with the arches in a moment between the late Roman wall and the foundation of the sixth-century basilica, which overlaps the same wall. In the same period the funerary use identified by the excavation of the area in front of the façade must have been started: C1 / 1, C3 / 1 seem to delimit structures of the related burials.

Group $\mathbf{F}$ is also entirely coherent with the stratigraphic analysis. It identifies the complete factory of the basilica with three late naves, founded on the L-shaped wall. C 13 and C 14, which constitute the walls of the southern small nave and C 112 - which represents the wall with pillars forming the northern perimeter of the central nave - have the same mortar. The semicircular apse C 15 was built with the same mortar as well. Also, the presence of this mortar in some walls located in the funerary area in front of the facade $(\mathrm{C} 1 / 2, \mathrm{C} 3 / 2)$ seems to indicate how, even in this period, the funerary use continues in that sector.

Interesting data, almost entirely coherent with the stratigraphic hypotheses also result from Group B. This group includes the mortars of the building intervention necessary to wall the arches of the late ancient wall, to obtain a solid base for the construction of the vault which, leaning against the L-shaped, constitutes the foundation of the northern nave of the sixthcentury church. In fact, this mortar is found in the shoulders of the vault on the southern side in support of the "L-wall", in C 110 , a specimen recovered from what remains of the vault itself

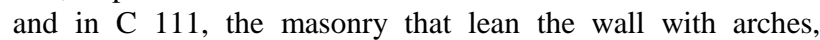
constituting the base of the new vault. In general, we should note that the mortars that distinguish the construction phase of the vault appear to be different from those of Group F, which we have seen characterize the construction of the basilica. This evidence seems to highlight how the construction of the basilica in the upper space of the L-shaped wall/embankment cannot be considered contextual to the construction of the northern vault, which forms the cryptoporticus and supports the nave of the church. It is possible to believe that in the first phase the basilica was built on the ground formed by the late imperial embankment (L-shaped wall) and that, in a first period, it has not yet been equipped with the downstream vault and north aisle. The vault that supports the North aisle and forms the cryptoporticus below must 6 th be built only later. The amphorae of the vault date to the 6th century (Roascio, 2018) Therefore, the 6th century would not seem to be the dating of the whole basilica, but only of the construction of a subsequent body leaning against its own northern side. In this case, the analysis of the mortars served to clarify better the dynamics of the 
construction site of the late ancient basilica, which was considered unitary. As we can see, the examination of the mineral-petrographic characteristics of the mortars in many cases led to obtaining data that is not in contrast with the stratigraphic reading of the elevations. On the one hand, that helps to validate with another method the data collected at the deductive level on the sequence of the walls. On the other hand, it sometimes allows us to clarify and deepen more clearly the relationships between the various construction phases, helping us to highlight activities that the archaeology of architecture alone had not entirely focused. The method is therefore profitable both as an analytical tool and as a method of control and validation of the sequences highlighted by the archaeological reading of the elevations.

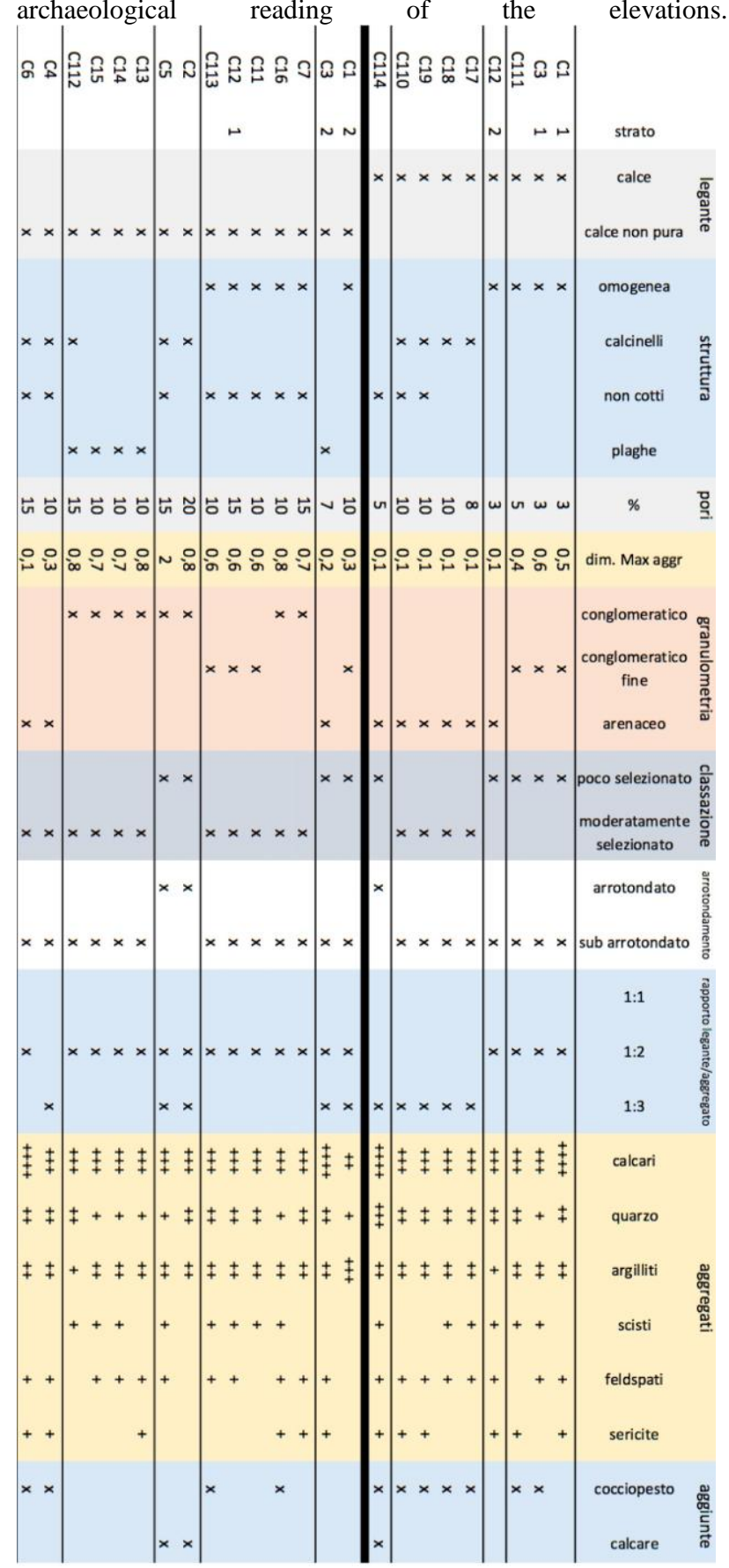

Figure 3. Table of minero-petrographic analysis.

\section{THE RADIOMETRIC DATING OF LIME CLUMPS: ANALYSIS OF THE RESULTS}

We decided to make extensive use of the radiometric dating of the lime clumps to reconstruct an archaeological sequence based on absolute dating (Pesce et al., 2009; Gallo et al., 1999; Pesce et al., 2012).

\section{sample C2 (US 720)}

expected dating: IX-X AD

CEDAD obtained dating: X-XII AD (900-920 2,4\%; 960-1050 $81,7 \%$; $1080-116011,4 \%)$. The obtained dating is consistent with what is estimated from an archaeological point of view, as it crosses the possible time range to the tenth century.

The triple obtained dating derives from the fact that the calibration curve descends in two points to then return to itself, providing more possible dating.

From an archaeological point of view, US 720 is the tomb structure that, located in the excavation area in front of the façade, intercepts and destroys the eastern portion of the late Roman bustum. Therefore, the chronology is an ante quem for the identified primary cremation and attests sepulchral phases around the X-XI century, allowing to hypothesize a continuity of the site's frequentation - at least for funerary use - when abandonment of the cult complex was considered plausible.

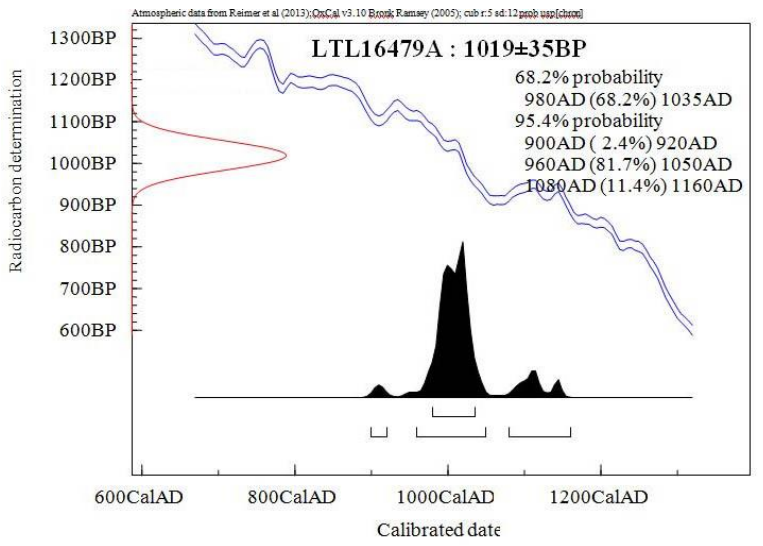

Figure 4. Radiocarbon data calibration of sample LTL16479A.

\section{sample C5 (USM 1032)}

expected dating: IV-V AD

CEDAD obtained dating: VII-IX AD (670-890 95,4\%) The obtained dating is not coherent with what we can estimate from an archaeological point of view. Despite being itself a possible time range, it is moved forward by at least two centuries. During the analysis of the sample and preparation, a central fracture in a clump was reported, with precipitation of carbonates inside, so we can imagine that the event influenced, for position and quantity, the dating, moving it forward at the time of reprecipitation. However, a real incompatibility between the stratigraphic data and the archaeometrical datum would have occurred only if the sample had revealed an instrumental dating preceding to the one supposed on the archaeological basis, but this did not happen. Unfortunately, it is still impossible to date USM 1032, which represents the remains of the quadrangular structure placed frontally to the apse, considered the possible ancient martyrial memory of $S$. Calocero, which would have originated the subsequent construction of the basilica in late antiquity. 


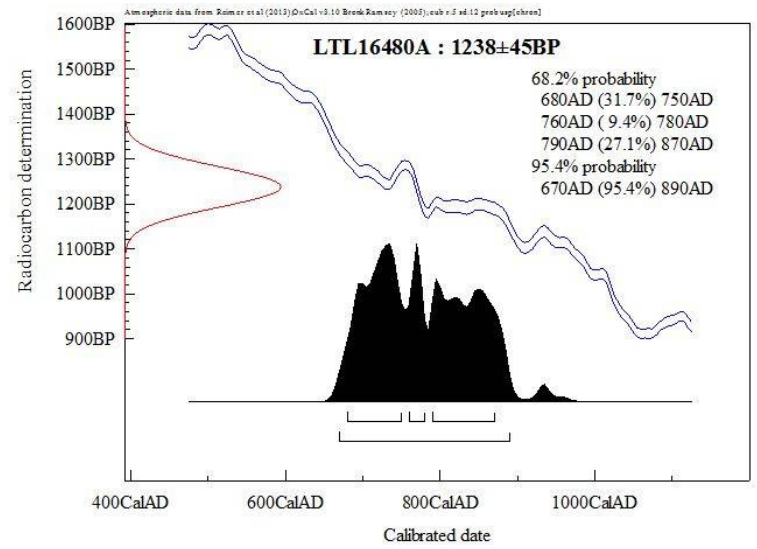

Figure 5. Radiocarbon data calibration of sample LTL16480A.

\section{sample C6 (US 124)}

expected dating: IV-V AD

CEDAD obtained dating: III-V AD (240-430 95,4\%)

The obtained dating is consistent with what we assumed from the archaeological point of view. The crossing with the archaeological estimate could restrict the dating to a period between 320 and $410 \mathrm{AD}$, which implies an instrumental probability of $59.8 \%$. From the archaeological point of view, US 124 represents a fragment of a possible floor level, visible in the western section of the so-called Lamboglia's "saggio a pozzo". Also, since there is no direct physical link between the two artifacts, the hypothesis formulated from an archaeological point of view is that the horizontal level US 124 could be connected with the nearby quadrangular masonry structure USM 1032, constituting its roof or an upper floor level. The chronology of the 4th-5th century could be entirely compatible with the hypothesis of a small memoria, still founded within the late imperial funerary precincts before the 6th-century basilica, in connection with the martyrdom remains.

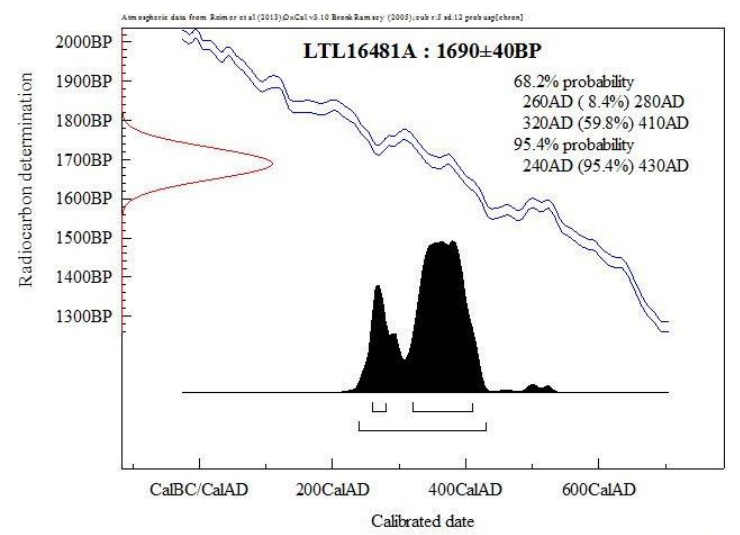

Figure 6. Radiocarbon data calibration of sample LTL16481A.

\section{sample C 16 ("L-shaped wall" - USM 1)}

expected dating: III AD

CEDAD obtained dating: I-III AD (60-240 al 95,4\%)

The obtained dating is consistent with what is estimated from an archaeological point of view. From the archaeological point of view, the archaeometric dating can be further restricted to the II-III century, by the study of the ceramic material found in the filling of the embankment (Roascio, 2010). The cross-reference of these data allows to definitively ascribe the great L-shaped containment wall, on which the Late Antique basilica will be founded, in the late imperial period. The discovery on the upper level of the embankment of a bustum dating to the end of III century (Roascio, c.d.s.) strongly reinforces the hypothesis that this structure was originally a funerary enclosure.

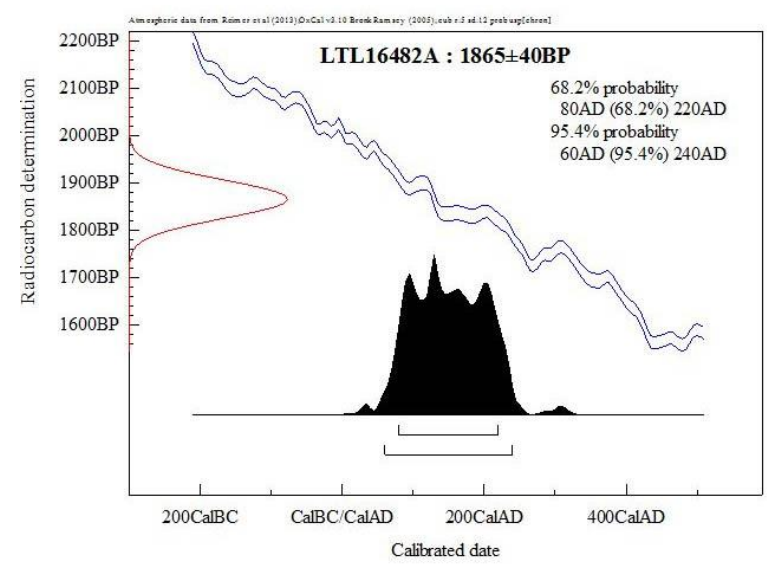

Figure 7. Radiocarbon data calibration of sample LTL16482A.

sample C 114 (USM 13)

expected dating: XIII-XIV AD

CEDAD obtained dating: XV-XVI AD (1401-1522 87,5\%; $1575-16247,9 \%)$

The dating obtained is not consistent with what is estimated from an archaeological point of view since, despite being in a possible time range, it is moved forward by many centuries.

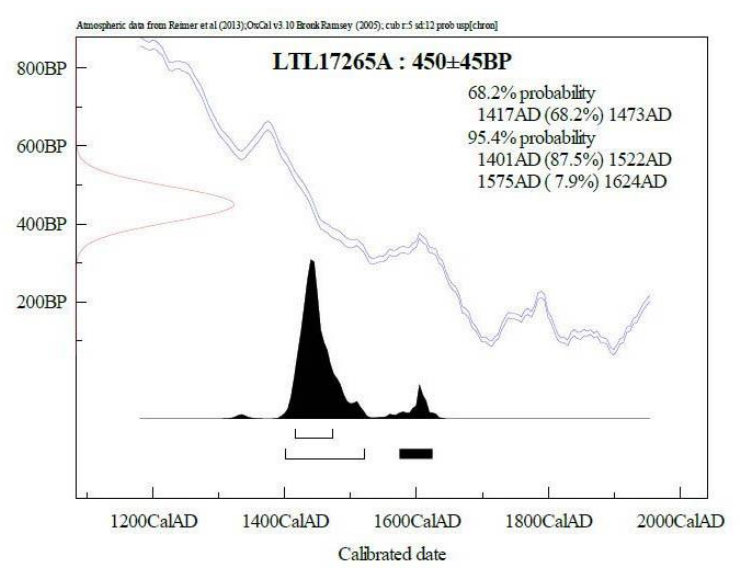

Figure 8. Radiocarbon data calibration of sample LTL17265A.

\section{CONCLUDING REMARKS ON ARCHAEOMETRIC METHODOLOGIES}

We have already discussed the potentialities of the mineralpetrographic analysis of mortars which, after all, is indeed not a novelty in the panorama of studies. The possibility of subjecting the carbonation time of the lime to radiocarbon dating allowing to attribute an absolute chronology to the mortars used in the masonry and, therefore, to the construction phases - is less known and applied. In our specific case, the contribution of radiocarbon dating of the grumi di calce (mortar clumps) has undoubtedly achieved significant results which, in principle, are compatible with archaeological proposals and confirm their chronologies and interpretations. The most significant limitation in the use of this technique is the cost of radiocarbon dating that does not allow the execution of extensive analysis campaigns. 


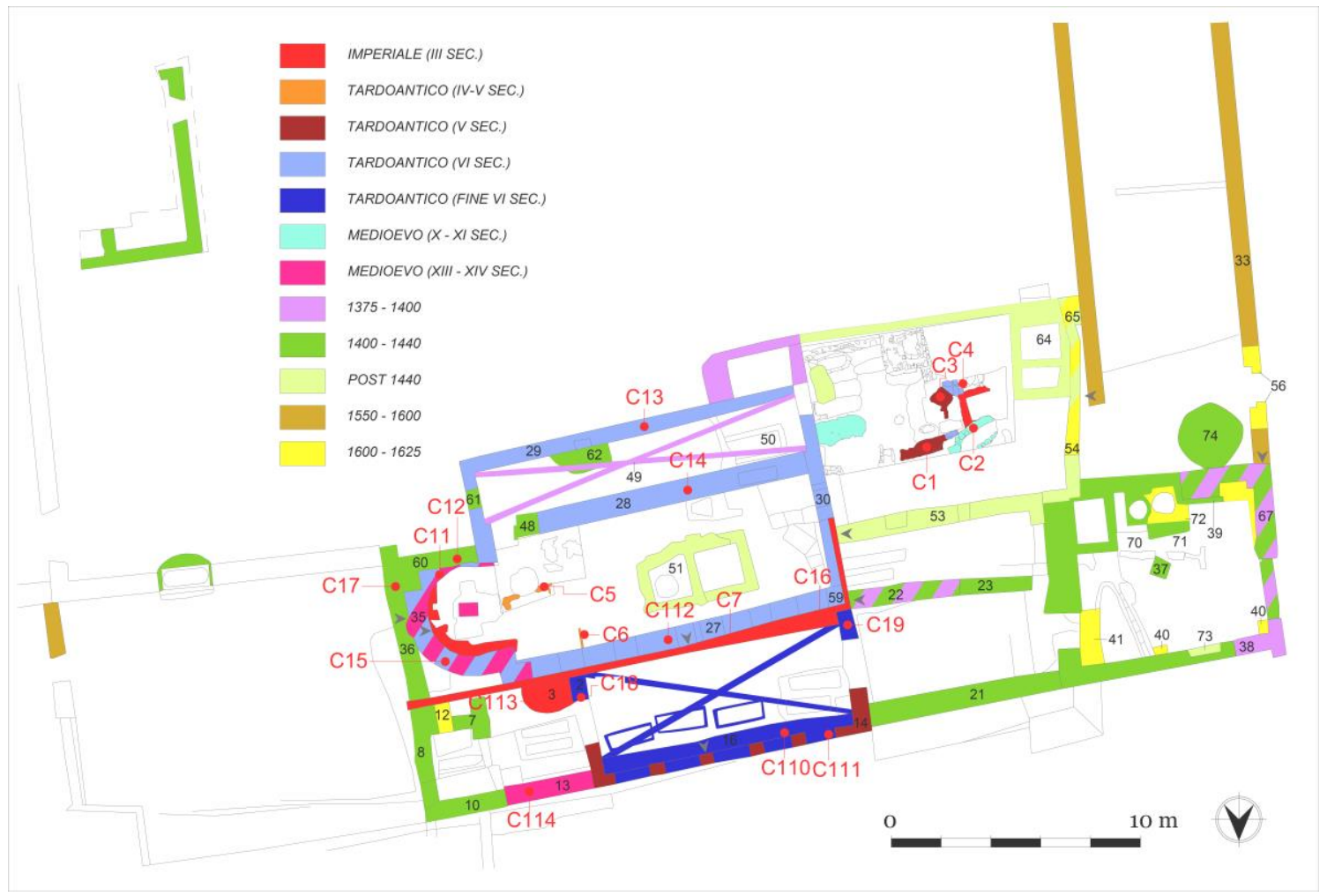

Figure 9. General plan of the site with indication of the main USMs (in black), sampling points of the withdrawals (in red) and reconstruction of the construction phases, obtained through the cross-reference of the various methods (archaeological excavation and elevations, minero-petrographic, dating of the lime clumps, C 14 on the bones, mensiochronology).

At a methodological and operational level, it is evident that a preliminary and correct treatment of the samples is necessary, before submitting them to the analysis laboratory. Also, a direct discussion between the preparatory technician and the archaeologist, who should not be completely unfamiliar with the method would be fundamental - as well as a general competence in directing archaeometric research in the right direction - of the most basic analysis techniques. Finally, a correct sampling is essential, carried out with rigorous procedures of the archaeological analysis of the masonry. Having said that, the potential of an archaeometric approach to the study of elevations is evident, especially if the archaeological data is scarce, as is generally the case in the excavation of churches, which return a small number of finds. Like any investigation methodology, there are strengths and weaknesses; it is up to the archaeologist to correctly lay down the fundamental problems to be faced with the analyzes; a direct dialogue between archaeologist and archaeometer is always recommendable.

The cross-reference of archaeological and archaeometric data according to the procedures of Global Archeology, if there is a real convergence of results (Mannoni et al., 1988), is the safest system for assessing the reliability of data and formulate correct interpretative hypotheses.

\section{ACKNOWLEDGEMENTS}

† Dedicated to Lauretta Tomasi.

\section{REFERENCES}

Gallo, N., Fieni, L., Martini, M., Sibilia, E., 1999. Archéologie du bâti, $14 \mathrm{C}$ et thermoluminescence: deux exemples en comparaison. Actes $d u 3^{\text {eme }}$ Congrés International $14 C$ et Archéologie. Evin, J., et al. (Eds.), Avril, Paris.

Gras, M., 2010. Prefazione. Albenga. Un antico spazio cristiano. Chiesa e monastero di San Calocero al Monte. Spadea Noviero, G., Pergola, Ph., Roascio, S., (Eds.), Genova, 9.

Lamboglia, N., 1947. Gli scavi nella zona paleocristiana di S. Calocero (Albenga). Rivista di Studi Liguri, III, 141-183.

Mannoni, T., Cabona, D., Ferrando, I., 1988. Archeologia globale del territorio. Metodi e risultati di una nuova strategia della ricerca in Liguria. Structures de l'habitat et occupation du sol dans les pays méditerranéens: les méthodes et l'apport de l'archéologie extensive. Roma-Madrid, 43-58.

Pergola, Ph., et al., 1990. La chiesa e il monastero di S. Calocero fuori le mura ad Albenga: relazione preliminare sulle campagne di scavo 1985 e 1986. Archeologia in Liguria, III. 2. Genova, 445-465.

Pergola, Ph., Roascio, S., 2010. Gli anni Ottanta: un percorso di scavo a San Calocero. Albenga. Un antico spazio cristiano. Chiesa e monastero di San Calocero al Monte. Spadea Noviero, G., Pergola, Ph., Roascio, S., (Eds.), Genova, 59-69. 
Pergola, Ph., Roascio, S., Dellu', E., Castigli,a G., 2018. Ricerche recenti e nuovi dati dal sito di San Calocero ad Albenga (Savona) tra Tardo Antico e Medioevo. Dinamiche insediative nelle campagne dell'Italia tra Tarda Antichità e Alto Medioevo - Settlement patterns in the countryside of Italy between Late Antiquity and the Early Middle Ages. Castrorao Barba, A., (ed.), Oxford, 57-72.

Pesce, G.L.A., Quarta, G., Calcagnile, L., D’Elia, M., Cavaciocchi, P., Lastrico, C., Guastella, R., 2009. Radiocarbon dating of lumps from aerial lime mortars and plasters: methodological issues and results from the S. Nicolò of Capodimonte Church (Camogli, Genoa - Italy). Radiocarbon, $51,2,867-872$.

Pesce, G.L.A., Ball, R., 2012. Dating of Old Lime Based Mixtures with the "Pure Lime Lumps" Technique. Radiocarbon Dating. Michalska Nawrocka, D., (ed.), Intech Editor, Slavka Krautzeka, 21-38.

Roascio, S., 2010. Gli interventi di scavo di Nino Lamboglia: metodologie, risultati e revisioni. Albenga. Un antico spazio cristiano. Chiesa e monastero di San Calocero al Monte. Spadea Noviero, G., Pergola, Ph., Roascio, S., (Eds.), Genova, 47-58.

Roascio, S., 2018. Il battistero di San Giovanni ad Albenga (SV). Le travagliate vicende di un cantiere tardoantico di lunga durata. Archeologia dell'Architettura, XXIII, 157-182.

Roascio, S. Albenga nella tarda antichità. Rinascita di una città, in c.d.s.

Roascio, S., Decri, A., Scrivano, S. Il sito di San Calocero di Albenga (SV). Approcci integrati di Archeologia dell'Architettura: dalle indagini minero-petrografiche alla datazione radiocarbonica dei "grumi di calce". Archeologia dell'Architettura, XXIV, c.d.s.

Roascio, S., Gavagnin, S., 2010. I resti in elevato del complesso: lettura archeologica dei volumi e delle murature. Albenga. Un antico spazio cristiano. Chiesa e monastero di San Calocero al Monte. Spadea Noviero, G., Pergola, Ph., Roascio, S., (Eds.), Genova, 211-231.

Spadea, G., 2010. Un progetto per Albenga: ricerca tutela e valorizzazione nel comlesso di San Calocero. Albenga. Un antico spazio cristiano. Chiesa e monastero di San Calocero al Monte. Spadea Noviero, G., Pergola, Ph., Roascio, S., (Eds.), Genova, 19-29.

Spadea, G., Pergola, Ph., Roascio, S., 2010. Albenga. Un antico spazio cristiano. Chiesa e monastero di San Calocero al Monte, Genova. 